\title{
Pengaruh Perputaran Modal Kerja, Likuiditas dan Pertumbuhan Penjualan terhadap Profitabilitas
}

\section{The Effect of Working Capital Turnover, Liquidity and Sales Growth on Profitability}

\author{
Virgadinda Anindita, Elmanizar \\ Accounting Study Program, Faculty of Economics and Business, YARSI University, Jakarta \\ Jalan Letjen. Suprapto, Cempaka Putih, Jakarta 10510 \\ Telepon (021) 4206674, 4206675, 4206676 \\ E-mail: elmanizar@yarsi.ac.id
}

KEYWORDS working capital turnover, liquidity, sales growth, profitability

ABSTRACT This study aims to determine the effect of working capital turnover, liquidity and sales growth on profitability in food and beverage sub-sector manufacturing companies listed on the Indonesia Stock Exchange in 20142017. This study utilizes secondary data of the financial statements of food and beverage subsector companies on the Indonesia Stock Exchange in 2014-2017 collected from the official website of the Indonesia Stock Exchange. The sampling technique used purposive sampling. The samples in this study were 11 companies on the Indonesia Stock Exchange. The analysis method used ratio analysis and multiple linear regression with a significant level of 5\%. The results showed that the working capital turnover, liquidity and sales growth affected significantly on profitability.

\section{PENDAHULUAN}

Profitabilitas merupakan salah satu indikator kemajuan dari suatu perusahaan yang dikatakan semakin baik, berkembang dan dapat bertahan hidup apabila profitabilitas perusahaan meningkat.

Perusahaan dalam mencapai tujuannya untuk memperoleh laba diperlukan modal untuk membiayai aktivitas operasional sehari-hari ataupun membiayai investasi jangka panjang perusahaan. Modal untuk keperluan aktivitas operasional perusahaan itu disebut modal kerja. Menurut Chen \&
Oetomo (2015) modal kerja atau yang biasa disebut dengan perputaran modal kerja/networking capital turnover (NWCTO) ini akan terus berputar setiap periodenya di dalam perusahaan.

Selain modal, faktor lain yang mempengaruhi profitabilitas adalah likuiditas yang mengacu pada kemampuan perusahaan untuk memenuhi kewajiban jangka pendeknya. Likuiditas dapat diukur dengan menggunakan current ratio (CR). Pertumbuhan penjualan/Sales of Growth (SOG) juga merupakan aspek penting yang menjadi sorotan bagi profitabilitas perusahaan. 
Pada penelitian ini digunakan Return on Asset (ROA) sebagai alat untuk mengukur profitablitas perusahaan. Menurut Riyanto (2012), ROA merefleksikan seberapa banyak perusahaan telah memperoleh hasil atas seluruh sumber daya keuangan yang ditanamkan pada perusahaan. Salah satu contoh nilai NWCTO, SOG dan ROA pada PT Mayora Indah Tbk. NWCTO (dari $4.17 \%$ menjadi $3.36 \%$ ) dan SOG (dari $17.9 \%$ menjadi $13.4 \%$ ) pada PT. MYOR pada tahun 2014-2017 mengalami penurunan namun penurunan ini tidak diikuti dengan ROA (dari 3.98\% menjadi $10.9 \%$ ), justru mengalami peningkatan selama 4 tahun tersebut. Menurut Chen dan Oetomo (2015) jika NWCTO naik, maka ROA akan naik juga. Sama halnya dengan SOG, hal ini sesuai dengan penelitian Nugroho (2011) bahwa jika SOG mengalami kenaikan maka ROA juga akan mengalami kenaikan.

Selain itu, nilai CR pada PT. MYOR pada tahun 2014-2017 mengalami peningkatan, begitu pula dengan ROA yang juga mengalami pengingkatan. Dimana yang seharusnya terjadi menurut Noviana (2015) bahwa jika CR mengalami penurunan, maka ROA akan naik, begitu pula sebaliknya.

Berdasarkan latar belakang tersebut, maka dalam penelitian perlu mengetahui pengaruh perputaran modal kerja, likuiditas dan pertumbuhan penjualan terhadap profitabilitas.

\section{METODOLOGI}

Penelitian ini merupakan penelitian deskriptif dengan pendekatan kuantitatif. Populasi yang digunakan dalam penelitian ini ada 18 perusahaan subsektor makanan dan minuman yang tercatat di Bursa Efek Indonesia periode 2014-2017.

Pengambilan sampel menggunakan metode Purposive Samplin., Pertimbangan/kriteria yang digunakan untuk memipilih sampel adalah:

1. Perusahaan manufaktur sektor makanan dan minuman yang go public di Bursa Efek Indonesia selama tahun 2014-2017. Perusahaan manufaktur sektor makanan dan minuman yang menerbitkan laporan keuangan secara lengkap dan konsisten selama tahun 2014-2017.

2. Perusahaan manufaktur sektor makanan dan minuman yang menghasilkan laba selama tahun 2014-2017.

3. Perusahaan manufaktur sektor makanan dan minuman yang menerbitkan laporan keuangan secara lengkap dan konsisten selama tahun 2014-2017.

Berdasarkan pada kriteria tersebut diatas, terdapat 10 perusahaan yang dijadikan sampel penelitian ini yaitu:

Tabel 1. Perusahaan Yang Menjadi Sampel Penelitian

\begin{tabular}{ll}
\hline \multicolumn{1}{c}{ Kode } & \multicolumn{1}{c}{ Nama Perusahaan } \\
\hline CEKA & Wilmar Cahaya Indonesia Tbk \\
DLTA & Delta Djakarta Tbk \\
ICBP & Indofood CBP Sukses Makmur Tbk \\
INDF & Indofood Sukses Makmur Tbk \\
MYOR & Mayora Indah Tbk \\
ROTI & Nippon Indosari Corporindo Tbk \\
SKBM & Sekar Bumi Tbk \\
SKLT & Sekar Laut Tbk \\
STTP & Siantar Top Tbk \\
ULTJ & Ultrajaya Milk Industry and Trading Company Tbk \\
\hline
\end{tabular}


Vaviabel indipenden dalam penelitian ini adalah: Modal Kerja atau Net Working Capital Turn Over (NWCTO), Likuiditas/Current Ratio (CR), dan Pertumbuhan Penjualan atau Sales Of Growth (SOG). Variabel dependennya adalah Profitabilitas dengan menggunakan rasio Return On Asset (ROA). Berikut merupakan rumus dari Perputaran Modal Kerja (NWCTO).

$$
\mathrm{NWCTO}=\frac{\text { Net Sales }}{\text { Net Working Capital }}
$$

\section{Likuiditas}

Dalam penelitian ini peneliti menggunakan current ratio (CR) untuk menghitung tingkat likuiditas perusahaan. Berikut ini merupakan rumus dari Current Ratio (CR):

\section{$\mathbf{C R}=\quad$ Current Assets Current Liabilities}

Pertumbuhan Penjualan

Penjualan merupakan salah satu sumber pendapatan perusahaan. Jika pertumbuhan penjualan perusahaan tetap stabil atau bahkan meningkat, dan biayabiaya dapat dikendalikan, maka laba yang diperoleh akan meningkat. Jika laba meningkat, maka keuntungan yang akan diperoleh investor juga dapat meningkat.

Menurut Kasmir (2012) menyatakan Rasio pertumbuhan (growth ratio) merupakan rasio yang menggambarkan kemampuan perusahaan mempertahankan posisi ekonominya di tengah pertumbuhan perekonomian dan sektor usahanya. Dalam rasio ini, yang dianalisis adalah pertumbuhan penjualan, pertumbuhan laba bersih, pertumbuhan pendapatan per saham, dan pertumbuhan dividen per saham.

Berikut merupakan rumus dari rasio pertumbuhan penjualan (SOG):

$$
\text { SOG }=\frac{s_{t-\left(s_{t-1}\right)}}{s_{t-1}} \times 100 \%
$$

\section{Profitabilitas}

Menurut

Sartono

(2012)

profitabilitas adalah kemampuan perusahaan memperoleh laba dalam hubungannya dengan penjualan, total aktiva maupun modal sendiri.

Pengertian rasio profitabilitas menurut Fahmi (2013) yaitu untuk menunjukan keberhasilan perusahaan didalam menghasilkan keuntungan.

Dalam penelitian ini menggunakan Return on Asset (ROA) Return on Asset (ROA). Berikut merupakan rumus dari ROA:

$$
\text { ROA }=\frac{\text { EAT }}{\text { Total Assets }}
$$

Metode Analisis Data dalam penelitian ini adalah analisis regresi berganda, dan Analisis Trend yaitu analisis yang berguna utnuk mengetahui perkembangan kinerja keuangan dengan cara membandingkan rasio-rasio keuangan perusahaan dari tahun-tahun. Analisis linear berganda dalam penelitian ini digunakan untuk menghitung besarnya pengaruh variable independen NWCTO, CR, SOG dependen ROA. Adapun bentuk model yang akan diuji dalam penelitian ini yaitu :

$\mathrm{Y}=\mathrm{a}+\mathrm{b} 1 \mathrm{X} 1+\mathrm{b} 2 \mathrm{X} 2+\mathrm{b} 3 \mathrm{X} 3+\mathrm{e}$

Metode pengujian terhadap hipotesis yang diajukan dilakukan pengujian secara parsial serta analisis koefisien determinasi, pengujian hipotesis tersebut dapat diterangkan sebagai berikut

1. Uji Parsial (Uji t)

Uji ini merupakan uji signifikasi (pengaruh nyata) variabel independen $(\mathrm{X})$ terhadap variabel dependen (Y) secara parsial. Uji t-statistik juga berarti uji keberartian koefisien (bi). Hal ini 
digunakan untuk menguji koefisien regresi secara parsial dari variabel independennya.

Kriteria pengambilan keputusan adalah sebagai berikut :

1) Jika t hitung > t tabel maka variabel independen i secara parsial berpengaruh terhadap variabel dependen.

Jika t hitung < $\mathrm{t}$ tabel maka variabel independen i secara parsial tidak berpengaruh terhadap variabel dependen.

2) Jika p-value $<\alpha(0,05)$ maka Ho ditolak, berarti variabel independen $\mathrm{i}$ berpengaruh signifikan terhadap variabel dependen.

Jika p-value $>\alpha(0,05)$ maka Ho diterima, berarti variabel independen

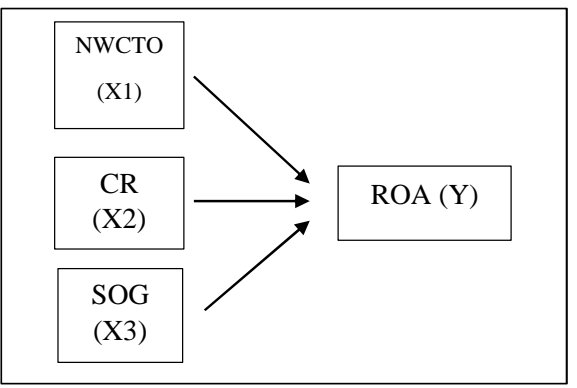

Gambar 1. Kerangka Pemikiran

ISI

\section{Pengaruh Perputaran Modal Kerja (NWCTO) Terhadap Profitabilitas (ROA)}

Pengaruh perputaran modal kerja terhadap profitabilitas menurut Djarwanto (2011) bahwa perputaran modal kerja (working capital turnover) adalah rasio antara penjualan dengan modal kerja, perputaran modal kerja yang tinggi menunjukkan semakin besar kemampuan perusahaan untuk memperoleh laba melalui penjualan. i tidak berpengaruh signifikan terhadap variabel dependen.

2. Koefisien determinasi $\left(\mathrm{R}^{2}\right)$

Nilai R2 besarnya antara nol dan satu (0 R2 1), jika mendekati satu maka kecocokan model dikatakan cukup untuk menjelaskan variabel dependen. Dapat dilihat dengan rumus sebagai berikut:

$$
\begin{aligned}
& \mathrm{Kd}=\mathrm{r}^{2} \times 100 \% \\
& \text { Dimana : } \\
& \mathrm{Kd}=\text { Koefisien Determinasi } \\
& \mathrm{R}^{2}=\text { Koefisien Kolerasi }
\end{aligned}
$$

Perputaran modal kerja, likuiditas dan pertumbuhan penjualan merupakan faktor yang berpengaruh terhadap profitabilitas perusahaan yang dalam penelitian ini diwakili oleh Return On Assets (ROA).

H 1: Perputaran Modal Kerja (NWCTO) Berpengaruh Positif dan Signifikan Terhadap Profitabilitas (ROA)

Hasil pengujian data menunjukkan bahwa variabel NWCTO memiliki nilai signifikan 0.030 artinya lebih kecil dari $0.05(0.030<0.05)$. Sedangkan jika dilihat dari nilai t hitung yang memiliki nilai sebesar 2.265 dengan derajat kebebasan (df) n-k (36) yang artinya $\mathrm{t}$ hitung $>\mathrm{t}$ tabel atau $2.265>$ 2.02809. Adapun nilai beta yang dihasilkan positif sebesar 1.593. Koefisiensi regresi variabel penjualan bertanda positif (+). Hal ini menunjukkan bahwa hubungan antara NWCTO terhadap ROA adalah searah. Hasil uji koefisien regresi dapat disimpulkan bahwa NWCTO berpengaruh positif terhadap ROA pada perusahaan manufaktur subsektor makanan dan minuman tahun 2014-2017 sehingga hipotesis pertama diterima.

Hasil ini sesuai dengan hasil penelitian yang dilakukan oleh Satriya dan Lestari (2014) menunjukkan bahwa 
terdapat pengaruh positif pada perputaran modal kerja terhadap profitabilitas (ROA). Sariyana, dkk (2016) menemukan hubungan positif pada NWCTO terhadap ROA. Hasil yang sama juga diperoleh Chen dan Oetomo (2015) yaitu terdapat pengaruh positif dan signifikan pada NWCTO terhadap ROA.

\section{Pengaruh Likuiditas Terhadap Profitabilitas (ROA)}

Menurut Kasmir (2012) rasio likuiditas digunakan untuk mengukur kemampuan perusahaan mambayar kewajiban atau utang yang segera jatuh tempo pada saat ditagih. Dalam penelitian ini likuiditas diukur dengan current ratio.

H2: Likuiditas (CR) Berpengaruh Negatif dan Signifikan Terhadap Profitabilitas (ROA)

Variabel $\mathrm{CR}$ memiliki nilai signifikan 0.048 artinya lebih kecil dari $0.05(0.048<0.05)$. Sedangkan jika dilihat dari nilai $t$ hitung yang memiliki nilai sebesar -2.044 dengan derajat kebebasan (df) n-k (36) yang artinya $\mathrm{t}$ hitung > t tabel atau -2.044>-2.02809. Adapun nilai beta yang dihasilkan negatif sebesar -0.293. Koefisiensi regresi variabel CR bertanda negatif (-). Hal ini menunjukkan bahwa hubungan antara $\mathrm{CR}$ terhadap ROA adalah tidak searah. Hasil uji koefisien regresi dapat disimpulkan bahwa Likuiditas berpengaruh negatif terhadap ROA pada perusahaan manufaktur subsektor makanan dan minuman tahun 2014-2017 sehingga hipotesis kedua diterima.

Hasil ini sesuai dengan hasil penelitian yang dilakukan oleh Nugroho (2011) menunjukkan bahwa CR berpengaruh negatif terhadap ROA. Hasil yang sama juga diperoleh Nurdianti
(2013) yaitu CR berpengaruh negatif terhadap ROA.

\section{Pengaruh Pertumbuhan Penjualan (SOG) Terhadap Profitabilitas (ROA)}

Menurut Swastha dan Handoko (2011) pertumbuhan atas penjualan merupakan indikator penting dari penerimaan pasar dari produk dan/atau jasa perusahaan tersebut, dimana pendapatan yang dihasilkan dari penjualan akan dapat digunakan untuk mengukur tingkat pertumbuhan penjualan. Semakin meningkat pertumbuhan penjualan maka profitabilitas yang diperoleh perusahaan akan menurun.

H3: Pertumbuhan Penjualan (SOG) Berpengaruh Positif dan Signifikan Terhadap Profitabilitas (ROA)

Variabel SOG memiliki nilai signifikan 0.032 artinya lebih kecil dari $0.05(0.032<0.05)$. Sedangkan jika dilihat dari nilai $\mathrm{t}$ hitung yang memiliki nilai sebesar 2.233 dengan derajat kebebasan (df) $\mathrm{n}-\mathrm{k}$ (36) yang artinya $\mathrm{t}$ hitung > t tabel atau $2.233>2.02809$. Adapun nilai beta yang dihasilkan positif sebesar 0.319. Koefisiensi regresi variabel SOG bertanda positif (+). Hal ini menunjukkan bahwa hubungan antara SOG terhadap ROA adalah searah. Hasil uji koefisien regresi dapat disimpulkan bahwa SOG berpengaruh positif terhadap ROA pada perusahaan manufaktur subsektor makanan dan minuman tahun 2014-2017, sehingga hipotesis ketiga diterima.

Hasil ini sesuai dengan penelitian yang dilakukan oleh Shintya (2017) yang hasilnya menunjukkan bahwa SOG memiliki pengaruh positif dan signifikan terhadap ROA. 


\section{Analisis Laporan Keuangan}

Pada penelitian ini analisis laporan keuangan menggunakan teknik analisis laporan keuangan Trend. Menurut Munawir (2014) Trend adalah suatu teknik analisis untuk mengetahui tendensi daripada keadaan keuangannya, apakah menunjukkan tendensi tetap, naik atau bahkan turun.

\section{Perputaran Modal Kerja Perusahaan Manufaktur Subsektor Makanan dan Minuman}

Pengaruh perputaran modal kerja terhadap profitabilitas menurut Djarwanto (2011) bahwa perputaran modal kerja (working capital turnover) adalah rasio antara penjualan dengan modal kerja. Pada Tabel 2, diperlihatkan perputaran modal perusahaan manufaktur sub sektor makanan dan minuman yang menjadi sampel penelitian.

Tabel 2. Perkembangan Perputaran

Modal Kerja Perusahaan Manufaktur Subsektor Makanan dan Minuman tahun 2014-2017

\begin{tabular}{ccccc}
\hline KODE & 2014 & 2015 & 2016 & 2017 \\
\hline INDF & 3,47 & 3,62 & 6,83 & 6,45 \\
SKLT & 26,2 & 24,3 & 15,6 & 16,4 \\
CEKA & 11,1 & 7,98 & 6,86 & 7,83 \\
DLTA & 1,33 & 0,92 & 0,85 & 0,73 \\
SKBM & 12,1 & 5,67 & 29,9 & 31,5 \\
STTP & 8,32 & 7,93 & 7,21 & 4,8 \\
ULTJ & 3,4 & 2,85 & 1,86 & 2,05 \\
ROTI & 16,7 & 5,21 & 4,01 & 1,93 \\
ICBP & 3,79 & 3,99 & 4,07 & 3,65 \\
MYOR & 4,17 & 3,44 & 3,78 & 3,36 \\
AVERAGE & 9,05 & 6,59 & 8,09 & 7,87 \\
MAX & 26,2 & 24,3 & 29,9 & 31,5 \\
MIN & 1,33 & 0,92 & 0,85 & 0,73
\end{tabular}

Sumber: $w w w . i d x . c o . i d$

Berdasarkan data yang telah diolah, diketahui bahwa perputaran modal kerja perusahaan manufaktur subsektor makanan dan minuman yang terdaftar di bursa efek Indonesia tahun 2014-2017 sangat berfluktuatif. Nilai NWCTO tertinggi diperoleh PT Sekar Laut Tbk (SKLT). Sedangkan nilai minimum diperoleh PT Delta Djakarta Tbk (DLTA). Rata-rata NWCTO perusahaan tahun 2014 sebesar 9.058, tahun 2015 sebesar 6.591, tahun 2016 sebesar 8.097, tahun 2017 sebesar 7.87.

Berikut grafik rata-rata NWCTO perusahaan manufaktur subsektor makanan dan minuman yang terdaftar di Bursa Efek Indonesia Tahun 2014-2017 untuk melihat kecenderungan baik berupa kenaikan atau penurunan yang terlihat pada Gambar 2 dibawah ini :

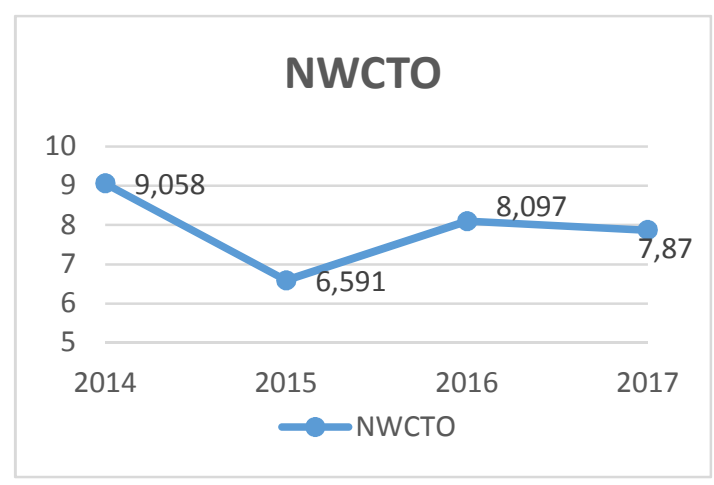

Gambar 2. Grafik Rata-rata Perputaran Modal Kerja Perusahaan Manufaktur Subsektor Makanan dan Minuman yang Terdaftar di BEI Tahun 20142017( Sumber: www.idx.co.id)

Berdasarkan Gambar 2 diatas pada grafik tersebut terlihat bahwa ratarata Perputaran Modal Kerja (NWCTO) perusahaan manufaktur subsektor makanan dan minuman mengalami kenaikan dan penurunan. Pada tahun 2014 ke tahun 2015 mengalami penurunan yaitu sebesar 9,058 menjadi 6,591, pada tahun 2015 ke tahun 2016 mengalami kenainan yaitu sebesar 6,591 menjadi 8,097 dan pada tahun 2016 ke tahun 2017 mengalami penurunan yaitu sebesar 8,097 menjadi 7,87. 


\section{Likuiditas Perusahaan Manufaktur Subsektor Makanan dan Minuman}

Menurut Kasmir (2012) rasio likuiditas digunakan untuk mengukur kemampuan perusahaan membayar kewajiban atau utang yang segera jatuh tempo pada saat ditagih. Semakin tinggi likuiditas semakin rendah profitabilitas dan sebaliknya semakin rendah likuiditas semakin tinggi profitabilitasnya. Perkembangan likuiditas dari 10 perusahaan dapat dilihat pada Tabel 4.

Berdasarkan data yang telah diolah, diketahui bahwa $\mathrm{CR}$ perusahaan manufaktur subsektor makanan dan minuman yang terdaftar di bursa efek indonesia tahun 2014-2017 sangat berfluktuatif. Nilai CR tertinggi diperoleh PT Delta Djakarta Tbk (DLTA). Sedangkan nilai minimum diperoleh PT Sekar Laut Tbk (SKLT). Rata-rata perputaran modal kerja perusahaan tahun
2014 sebesar 208.74, tahun 2015 sebesar 218.61, tahun 2016 sebesar 251.87, tahun 2017 sebesar 262.22.

Berikut grafik rata-rata Likuiditas (CR) perusahaan manufaktur subsektor makanan dan minuman yang terdaftar di Bursa Efek Indonesia Tahun 2014-2017 untuk melihat kecenderungan baik berupa kenaikan atau penurunan yang terlihat pada Gambar 3 dibawah ini.

Berdasarkan gambar 3 diatas pada grafik tersebut terlihat bahwa rata-rata Likuiditas (CR) perusahaan manufaktur subsektor makanan dan minuman mengalami kenaikan. Pada tahun 2014 ke tahun 2015 mengalami kenaikan yaitu sebesar 208.74 menjadi 218.62, pada tahun 2015 ke tahun 2016 mengalami kenainan yaitu sebesar 218.62 menjadi 251.87 dan pada tahun 2016 ke tahun 2017 mengalami kenaikan yaitu sebesar 251.87 menjadi 262.22 .

Tabel 4. Perkembangan Likuiditas (CR) Perusahaan Manufaktur Subsektor Makanan dan Minuman tahun 2014-2017

\begin{tabular}{lcccc}
\hline \multicolumn{1}{c}{ KODE } & 2014 & 2015 & 2016 & 2017 \\
\hline INDF & 180,74 & 170,53 & 150,81 & 150,27 \\
SKLT & 118,38 & 119,25 & 131,53 & 126,31 \\
CEKA & 146,56 & 153,47 & 218,93 & 222,44 \\
DLTA & 447,32 & 642,37 & 760,39 & 863,78 \\
SKBM & 147,71 & 114,71 & 110,72 & 163,54 \\
STTP & 148,42 & 157,89 & 165,45 & 264,09 \\
ULTJ & 334,46 & 153,47 & 218,93 & 222,44 \\
ROTI & 136,54 & 205,34 & 296,23 & 244,35 \\
ICBP & 218,32 & 232,6 & 240,68 & 242,83 \\
MYOR & 208,99 & 236,53 & 225,02 & 122,13 \\
\multicolumn{1}{c}{ AVERAGE } & 208,74 & 218,62 & 251,87 & 262,22 \\
$\quad$ MAX & 447,32 & 642,37 & 760,39 & 863,78 \\
$\quad$ MIN & 118,38 & 114,71 & 110,72 & 122,13 \\
\hline
\end{tabular}

Sumber: www.idx.co.id 
Pertumbuhan Penjualan Perusahaan Manufaktur Subsektor Makanan dan Minuman dan Minuman

Menurut Swastha dan Handoko (2011) pertumbuhan atas penjualan merupakan indikator penting dari penerimaan pasar dari produk dan/atau jasa perusahaan tersebut, dimana pendapatan yang dihasilkan dari penjualan akan dapat digunakan untuk mengukur tingkat pertumbuhan penjualan. Semakin meningkat pertumbuhan penjualan maka profitabilitas yang diperoleh perusahaan akan menurun. SOG dari 10 perusahaan dapat dilihat pada Tabel 5.

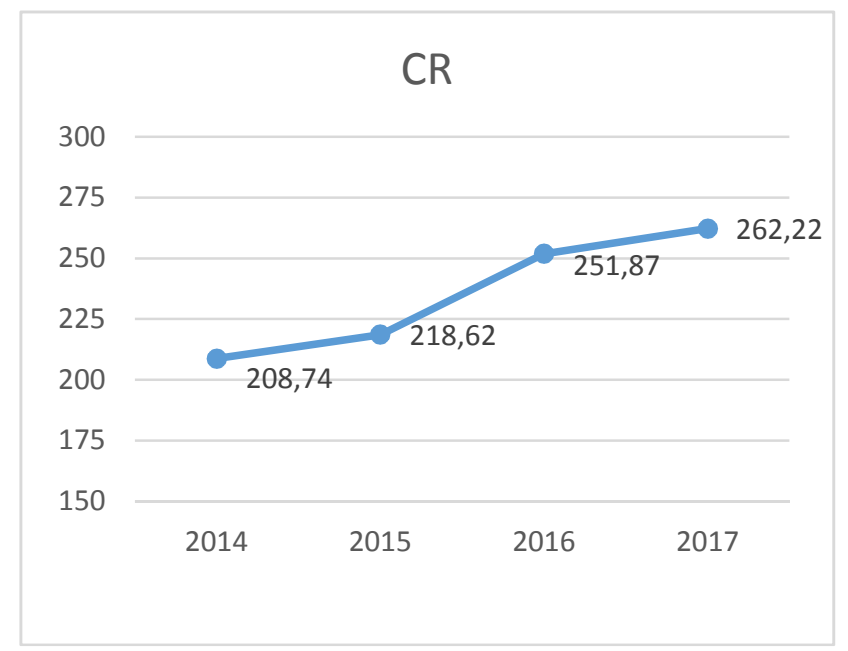

Gambar 3. Grafik Rata-rata Likuiditas (CR) Perusahaan Manufaktur Subsektor Makanan dan Minuman yang Terdaftar di BEI Tahun 20142017(Sumber: $w w w . i d x . c o . i d)$

Tabel 5. Perkembangan Pertumbuhan Penjualan (SOG) Perusahaan Manufaktur Subsektor Makanan dan Minuman tahun 2014-2015

\begin{tabular}{ccccc}
\hline KODE & 2014 & 2015 & 2016 & 2017 \\
\hline INDF & 10,2 & 0,74 & 4,2 & 5,15 \\
SKLT & 20,2 & 9,35 & 11,9 & 9,63 \\
CEKA & 46,2 & $-5,8$ & 18,1 & 3,46 \\
DLTA & 1,41 & -20 & 10,8 & 0,3 \\
SKBM & 14,2 & -8 & 10,19 & 22,7 \\
STTP & 28,1 & 17,2 & 3,33 & 7,47 \\
ULTJ & 13,2 & 12,2 & 6,65 & 4,13 \\
ROTI & 24,9 & 15,7 & 16 & $-1,2$ \\
ICBP & 19,6 & 5,72 & 8,59 & 3,31 \\
MYOR & 17,9 & 4,58 & 23,8 & 13,4 \\
AVERAGE & 19,59 & 3,17 & 11,36 & 6,83 \\
MAX & 46,2 & 17,2 & 23,8 & 22,7 \\
MIN & 1,41 & -20 & 3,33 & $-1,2$ \\
\hline
\end{tabular}


Berdasarkan data yang telah diolah, diketahui bahwa SOG perusahaan manufaktur subsektor makanan dan minuman yang terdaftar di bursa efek Indonesia tahun 2014-2017 sangat berfluktuatif. Nilai SOG tertinggi diperoleh PT Wilmar Cahaya Indonesia Tbk (CEKA), Sedangkan nilai minimum diperoleh PT Delta Djakarta Tbk (DLTA). Rata-rata perputaran modal kerja perusahaan tahun 2014 sebesar 19.59, tahun 2015 sebesar 3.17, tahun 2016 sebesar 11.36, tahun 2017 sebesar 6.83 .

$\begin{array}{lcr}\text { Berikut } & \text { grafik } & \text { rata-rata } \\ \text { pertumbuhan } & \text { penjualan } & \text { (SOG) } \\ \text { perusahaan } & \text { manufaktur } & \text { subsektor }\end{array}$ makanan dan minuman yang terdaftar di Bursa Efek Indonesia Tahun 2014-2017 (Gambar 4) dibawah ini :

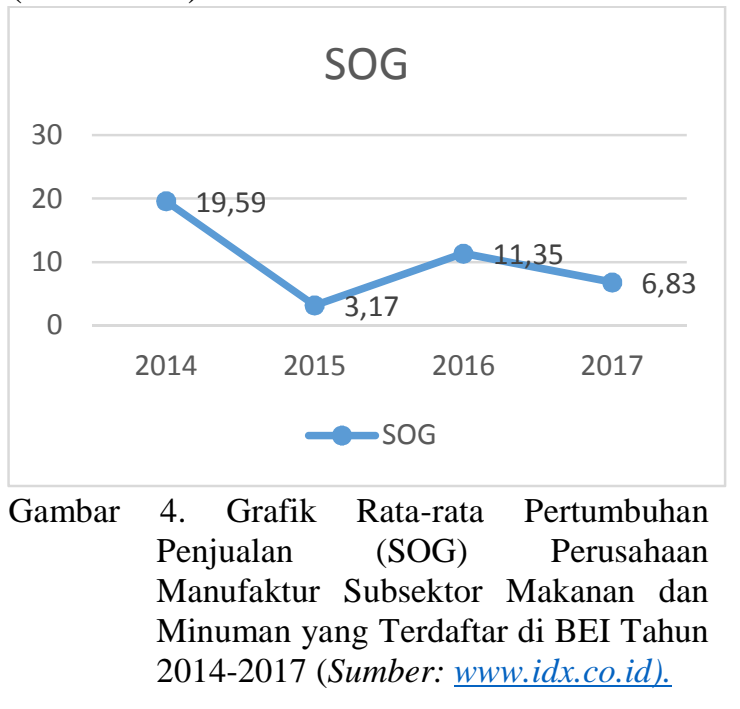

Berdasarkan Gambar 4 diatas pada grafik tersebut terlihat bahwa ratarata Pertumbuhan Penjualan (SOG) perusahaan manufaktur subsektor makanan dan minuman mengalami kenaikan dan penurunan. Pada tahun 2014 ke tahun 2015 mengalami penurunan yaitu sebesar 19.59 menjadi 3.17, pada tahun 2015 ke tahun 2016 mengalami kenainan yaitu sebesar 3.17 menjadi 11.35 dan pada tahun $2016 \mathrm{ke}$ tahun 2017 mengalami penurunan yaitu sebesar 11.35 menjadi 6.83 .

\section{Profitabilitas (ROA) Perusahaan Manufaktur Subsektor Makanan dan Minuman}

Menurut Kasmir (2012) ROA digunakan untuk menunjukkan kemampuan perusahaan menghasilkan laba dengan menggunakan total aset yang dimiliki. Perkembangan profitabilitas dari 10 perusahaan dapat dilihat pada Tabel 6 .

Tabel 6. Perkembangan Profitabilitas (ROA) Perusahaan Manufaktur Subsektor Makanan dan Minuman tahun 2014-2015

\begin{tabular}{ccccc}
\hline KODE & 2014 & 2015 & 2016 & 2017 \\
\hline INDF & 5,85 & 4,04 & 6,41 & 5,99 \\
SKLT & 4,97 & 5,32 & 3,63 & 3,61 \\
CEKA & 7,71 & 3,19 & 7,17 & 17,5 \\
DLTA & 29 & 18,5 & 21,3 & 20,9 \\
SKBM & 2,25 & 1,59 & 9,22 & 13,7 \\
STTP & 9,67 & 7,26 & 7,45 & 9,22 \\
ULTJ & 16,7 & 14,8 & 9,71 & 13,7 \\
ROTI & 8,8 & 10 & 9,58 & 2,97 \\
ICBP & 16,8 & 15 & 12,6 & 11,2 \\
MYOR & 3,98 & 11 & 10,8 & 10,9 \\
AVERAGE & 10,57 & 9,07 & 9,79 & 10,97 \\
MAX & 29 & 18,5 & 21,3 & 20,9 \\
MIN & 2,25 & 1,59 & 3,63 & 2,97 \\
\hline
\end{tabular}

Sumber: $w w w . i d x . c o . i d$

Berdasarkan data yang telah diolah, diketahui bahwa ROA perusahaan manufaktur subsektor makanan dan minuman yang terdaftar di bursa efek indonesia tahun 2014-2017 sangat berfluktuatif. Pada tahun 2014-2017, nilai ROA tertinggi diperoleh PT Delta Djakarta Tbk (DLTA). Sedangkan nilai minimum diperoleh PT Sekar Bumi Tbk 
(SKBM). Rata-rata perputaran modal kerja perusahaan tahun 2014 sebesar 10.57, tahun 2015 sebesar 9.07, tahun 2016 sebesar 9.79, tahun 2017 sebesar 10.97.

\begin{tabular}{lrr}
$\quad$ Berikut & \multicolumn{1}{c}{ grafik } & rata-rata \\
pertumbuhan & penjualan & (SOG) \\
perusahaan & manufaktur & subsektor \\
makanan dan minuman yang terdaftar di & \\
Bursa Efek Indonesia Tahun & $2014-2017$
\end{tabular}

(Gambar 5) dibawah ini :

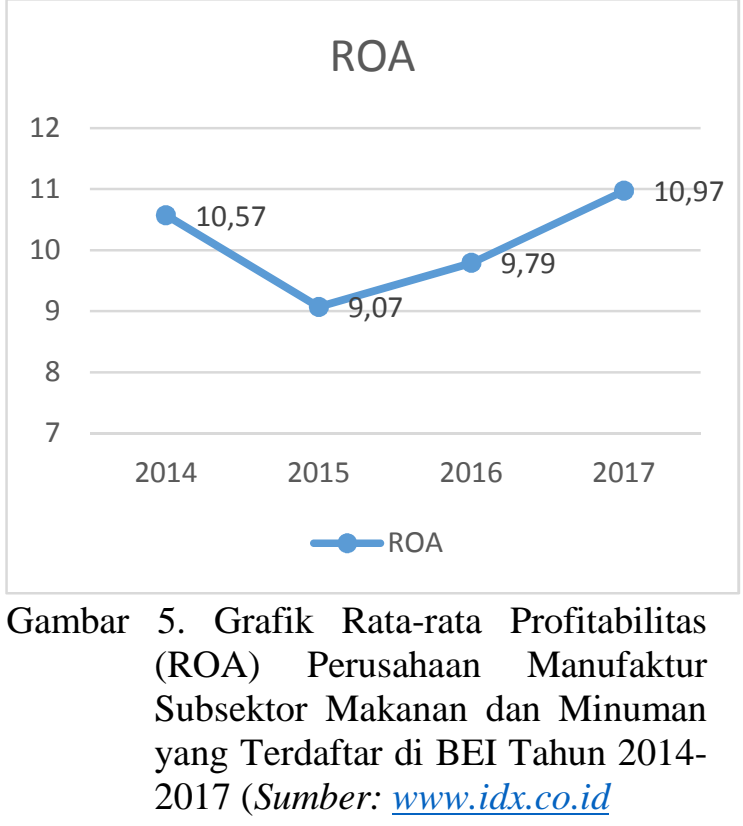

Berdasarkan Gambar 5 diatas pada grafik tersebut terlihat bahwa ratarata Pertumbuhan Penjualan (SOG) perusahaan manufaktur subsektor makanan dan minuman mengalami kenaikan dan penurunan. Pada tahun 2014 ke tahun 2015 mengalami penurunan yaitu sebesar 10.57 menjadi 9.07, pada tahun 2015 ke tahun 2016 mengalami kenainan yaitu sebesar 9.07 menjadi 9.79 dan pada tahun 2016 ke tahun 2017 mengalami kenaikan yaitu sebesar 9.79 menjadi 10.97 .

\section{PENUTUP}

Perputaran modal terdapat pengaruh positif dan signifikan terhadap profitabilitas (ROA). Likuiditas berpengaruh negatif dan signifikan terhadap profitabilitas (ROA). Pertumbuhan penjualan pengaruh positif dan signifikan terhadap profitabilitas (ROA).

\section{DAFTAR PUSTAKA}

Chen, S., Oetomo, W.H. 2015. Pengaruh Leverge, Likuiditas dan Perputaran Modal Kerja Terhadap Protailitas. Jurnal Ilmu dan Riset Manajemen, Vol. 4, No.10.

Djarwanto. 2011. Pokok-Pokok Analisis Laporan Keuangan. Edisi Kedua. BPFE. Yogyakarta

Fahmi, I. 2013. Analisis Laporan Keuangan, Bandung: Alfabeta

Kasmir. 2012. Analisis Laporan Keuangan. Rajawali Pers, Jakarta

Munawir. 2014. Analisis laporan Keuangan Edisi keempat. Yogyakarta: Liberty

Noviana, W. 2015. Analisis Perputaran Modal Kerja, Efisiensi dan Solvabilitas Terhadap Profitabilitas Perusahaan Konstruksi di Bursa Efek Indonesia tahun 2010-2013 dan Tinjauannya dari Sudut Pandang Islam. Skrispsi. Universitas Yarsi. Jakarta

Nugroho, E. 2011. Analisis Pengaruh Likuiditas, Pertumbuhan Penjualan, Perputaran Modal Kerja, Ukuran Perusahaan Dan Leverage Terhadap Profitabilitas Perusahaan. Universitas

Diponegoro. Semarang. 
Nurdianti, S. 2013. Pengaruh Likuiditas Terhadap Profitabilitas (Studi Kasus PT.Telekomunikasi ndonesia) Skripsi, Fakultas Ekonomi Universitas Gunadarma Jakarta

Riyanto, B. 2012. Dasar-dasar Pembelanjaan. Edisi 4, Yogyakarta: BPFE

Sariyana, B.M., Yudiatmaja, Fridayana dan Suwendra, I.W.. 2016. Pengaruh Perputaran Modal Kerja dan Likuiditas Terhadap Profitabilitas (Studi Pada Perusahaan Food and Beverages). Jurnal Bisma Universitas Pendidikan Ganesha Jurusan Manajemen, Vol. 4.

Sartono, A. 2012. Manajemen Keuangan Teori dan Aplikasi. Edisi 4. BPFE.Yogyakarta.
Satriya, I.M.D.,Lestari, P.V. 2014. Pengaruh Perputaran Modal Kerja Terhadap Profitabilitas Perusahaan. Jurnal Ilmiah Mahasiswa FEB.3(7): 1927-1942.

Shintya, M.N.. 2017. Pengaruh Leverage dan Pertumbuhan Penjualan Terhadap Profitabilitas Pada Perusahaan Sub Sektor Kosmetik yang Terdaftar di Bursa Efek Indonesia. Skripsi, Fakultas Ekonomi, Universitas Pakuan Bogor.

Sugiyono. 2014. Metode Penelitian Pendidikan Pendekatan Kuantitatif, Kualitatif dan R\&D. Bandung: Alfabeta.

Swastha, B., Handoko, H. 2011. Manajemen Pemasaran-Analisis Perilaku Konsumen. Yogyakarta : BPFE. 